\title{
Persuasive Strategies of Jordanian Government in Fighting Covid-19
}

\author{
Asim Ayed Alkhawaldeh \\ Asim-alkhawaldeh@aabu.edu.jo \\ Al-alBayt University, Jordan
}

\begin{abstract}
Since the outbreak of Covid-19 in March 2020 in Jordan that has continued to grow and impact all spheres of our lives, the government has been struggling to curb the pandemic through a range of safety and health measures. To this end, the government officials have employed diverse linguistic strategies in different media outlets to realize persuasion on the target audience in order to increase their awareness about the ongoing crisis and win public compliance and cooperation. Therefore, the present paper seeks, as its overriding goal, to explore the common linguistic strategies used by the Jordanian government to enhance its credibility and convince the public of the importance of effective adherence to its Covid-19 related policies (e.g. social distancing, face mask wearing, and self-hygiene). As an eclectic method of inquiry, the study draws generally on the perspective of discourse analysis and pragmatics. In addition, our analysis is informed by a corpus-based approach. The synthesis of our findings demonstrates that the government consistently and systematically utilizes various strategies for its persuasive intention (e.g. metaphor, repetition, and religious quotation). It also shows that the rationale beyond the respective persuasive techniques seems to win public compliance and cooperation, reassure the public, undermine opponent's counterclaims, and project a trustworthy and praiseworthy image.
\end{abstract}

Keywords: Covid-19; Persuasive Strategies; Interviews; Corpus; Jordanian government

\section{INTRODUCTION}

Since the outbreak of the novel coronavirus, governments worldwide have been struggling to face this unprecedented situation by taking quick and decisive action to contain the virus spread and mitigate its dire consequences. Therefore, different means of mass media such as TV, radio, newspaper, and social media platforms have been employed to increase the public awareness about the severe impact of this virus mainly on health, economy, and lifestyle. To this end, governments release and disseminate accurate and timely information about the coronavirus disease (e.g. symptoms, medical treatment, and protective and preventive measures). They also hold daily briefings (including number of infected cases and death toll, and any new pertinent policies) and conduct media interviews with officials, specialists and experts to correct fake news and false information shared through social media.

To cope with the pandemic, governments attempt to influence public opinion so as to gain an immediate and popular acceptance for their policies. Therefore, they make use of persuasive strategies to win public compliance with what is critical to the success of their efforts in the handling of the Covid-19 pandemic.

Like other governments, the government of Jordan has been put under pressure to fight the virus by communicating regularly its views, policies, achievements, and updates pertaining to the ongoing Covid-19 crisis to the public. This communication is apparently informational but ultimately intends to persuade the public. The government presents a range of safety and protection measures, calling the public for adhering to the respective measures in order to control the spread of the coronavirus and ward off its unpleasant repercussions, especially, on health and economy. The government enhances its communicative messages by offering an 
array of effective rationales to make its claims credible to the target audience and by making use of different strategies to influence Jordanians' attitude and behaviors in its favor.

Covid-19 has recently established its own specialized discourse, providing scholars with a source of data for academic research, which has drawn scholarly attention to explore this discourse from linguistic perspectives (Tan et al., 2020). However, I noticed that persuasion in Covid-19 discourse has been underexplored, particularly, in Arabic context, which may be due to the novelty of the virus. This certainly calls for undertaking a linguistic study or studies to shed some light on this worthy area of research.

As an integral part of daily communication, we use persuasion for a myriad of different intentions. It may, for instance, convince others to think or behave in a certain way, to agree with a viewpoint, to accept an argument, to believe in a cause, to support a plan or suggestion, to trust a policy or decision, to comply with a regulation, share a moral value, or to rally behind a person or an entity (Lee, 2005).

From the perspective of discourse analysis and pragmatics, the aim of the present study is to examine in greater detail the linguistic strategies of persuasion commonly employed by Jordanian officials in media discourse on the Covid-19 pandemic to gain public compliance with the government's policies on handling the ongoing pandemic. The data for the purpose of the study are drawn from media interviews with the government officials on different Jordanian outlets (TV and radio). More elaboration on persuasive strategies and media discourse will be given in the following two sections.

\section{PERSUASIVE STRATEGIES}

Essential for this paper is to define persuasion and its linguistic strategies. As part of argumentation in a general sense, persuasion can be defined as a process that aims at affecting, changing or strengthening the attitudes, beliefs, or behaviors of the target audience through the transmission of a message according to the persuader's viewpoint in a typically implicit manner (Perelman, 1982; O’Keefe, 2002; Virtanen \& Halmari, 2005; Soules, 2015).

Although it has been defined differently from various perspectives in the literature, it is beyond the scope of the present study to tackle these definitions. However, it can be claimed that all the proposed definitions of persuasion reviewed for the purpose of the present study tend to be relatively close, acknowledging the fact of influencing someone' thoughts.

With regard to persuasive strategies, Johnstone (1989) proposes the following definition, which is adopted for the goal of the present investigation:

"Persuasive strategies are the range of options from which a speaker selects in deciding on an appropriate tactic or combination of tactics for persuasion in a given situation" (p.134)

The diverse strategies of persuasion have one thing in common: they are used to substantiate the persuader's claims, messages or arguments, thus, more persuasive effects and attitude change are produced. Essentially, persuaders make use of strategies whose goal is to offer a set of attitudes or behaviors that would be advisable for addressees to align themselves with for their country, their safety, etc. (Pedrini, 2017). Persuasion operates in a wide variety of settings, including politics, economics, religion, health, media, marketing, and legal advocacy.

Persuasion is undoubtedly an ancient art that dates back to Greek classical rhetoricians (around the $4^{\text {th }}$ century B.C.E) such as Plato and Aristotle (O'Keefe, 2002). They recognized this art as a form of rhetoric whose indispensable components for successfully communicating one's ideas were logic and reasoning (Pedrini, 2017)

As the first general theory of persuasion, whose content is still immensely relevant in contemporary studies on persuasion, Aristotle authored his seminal book Rhetoric, in which 
guidelines were propounded for how orators were to produce their discourse to influence their audience (Pedrini, 2017). His theory proposed three distinct modes of persuasion (commonly known as rhetorical appeals), which has provided a solid basis for modern communication (Pedrini, 2017): ethos (appeal to the speaker' credibility), pathos (appeal to the addressee's emotions), and logos (appeal to rationality)

From Aristotle's time to today, the art of persuasion has developed and received scholarly attention in various cultures, disciplines, languages, and genres (Pelclova \& Lu, 2018). More particularly, scholars have been interested in the most persuasive techniques utilized to harness a speaker or writer's message in order to influence attitudes of others (Perloff, 2017).

The notion of persuasion is a well-established area in discourse analysis domain, which typically involves two parties: the persuader and the persuadee. In media discourse, persuasive process attempts deliberately and purposefully to sway mass public attitude in favor of the intents of the state or non-state institutions sending persuasive messages (Soules, 2015). Broadly speaking, the practice of persuasion in media discourse is associated with a centralized body e.g. governments, political parties, interest groups (pressure groups), and individuals with specific agendas (Soules, 2015).

A discourse persuasive situation is marked by a problem that prompts the speaker to produce an appropriate argument to persuade the audience effectively, accompanied often with focus on style, word choices, and tone needed to meet the discourse ends (Berger \& Stanchi, 2018). With this in mind, any treatment of persuasive communication must concern itself with an addressee or audience. Furthermore, to lessen or eliminate the audience's resistance to a particular message and gain their support, a wide variety of persuasive techniques can be employed.

As part of their communicative competence, Johnstone (1989) argues that people have access to a broad range of persuasive strategies but they do not use the same ones in every situation. She exemplifies that sometimes we use logic; sometimes we employ emotions or threats, sometimes we repeat what we want, sometimes we tell short stories. In cross cultural contexts, she distinguishes three persuasive strategies: quasilogical persuasion (to use formal reasoning, characterized by the use of conditionals and logical connectives), presentational persuasion (to evoke emotions of others, characterized by alliteration, repetition, and metaphor), and analogical persuasion (to use traditional wisdom, characterized by the use of parables, proverbs, and doctrinal texts). In another study on Arabic, Johnstone (1987) claims that repetition is the most common and salient mechanism for persuasion.

Persuasive process, Virtanen and Halmari (2005) point out, is massively affected by the socio-cultural and situational context in which it occurs and its linguistic features vary from genre to genre. They acknowledge that the selection of any linguistic strategy is tangibly influenced by the dynamic, interactive nature of persuasion and dictated by the audience in any given situation, which needs to be taken into consideration when describing a text whose intention is to persuade. Similarly, Beebe and Beebe (2018) highlight that the use of specific persuasive strategies depends heavily on the target audience, message, and desired response. Emotion-arousing expressions and metaphors, according to them, can be effectively employed as persuasive techniques by a public speaker to sway his listeners into his viewpoint. Speeches that use stylistics devices mainly metaphors and similes are more persuasive than those which do not (Beebe \& Beebe, 2018).

\section{MEDIA DISCOURSE}

Media discourse is a broad term that refers to a public form of interaction through a broadcast platform (written or spoken), in which the discourse is oriented toward readers, listeners, or 
viewers (O'Keeffe, 2011). It includes a wide variety of communication channels used to reach a large number of people such as TV, radio, newspapers, and social media. In its narrowest sense, media discourse refers, for example, to interviews, chat shows, and phone-ins (O'Keeffe 2011). Media discourse has been described as one of the most effective and powerful means of persuasion. That is, it has generally persuasive power, in the sense that the media discourse mainly has the potential to influence the minds and actions of viewers or readers (Van Dijk 1996).

Mass media (e.g. TV, press, radio, and social media) has been characterized as a widely used area for persuasion. More specifically, persuasive practices have become more viral and frenetic since the advent of social media such as Facebook, Twitter, and Instagram (Perloff, 2017). Social activists indomitably utilize persuasion to help change religious, racial, and gender attitudes in society (Vin, 2019). Healthcare professionals also launch untold campaigns to change people's thinking about smoking, drugs, and alcohol, etc. (Parsons, 2013). Party leaders resort to persuasion to influence the public to win their votes or move them toward a particular position (Charteris-Black, 2011). Government officials always make persuasive statements for defense and legitimization of their policies (Ho, 2016). A lawyer in a courtroom tries to present persuasive advocacy to move judges to make a judgment in favor of his client (Porto, 2020). Persuasion is found in sermons, preachers attempt to exhort their congregation to repent and establish a good relation with God (Adam, 2017).

The question of how language is used in media discourse (interviews in particular) has been of interest to scholars and linguists (Fairclough, 1995). O'Keeffe (2011) points out that the online availability of media discourse, especially, television and radio stations makes it increasingly attractive for discourse analysts. Within the field of discourse analysis, the structures and functions of media discourse are systematically examined in its social, political, and cultural contexts (Van Dijk, 1996). As an analytical framework, Pragmatics (e.g. politeness, and speech acts) can also play a key role within the study of spoken media discourse (O’Keeffe, 2011).

\section{LITERATURE REVIEW}

The present section will review the previous studies that deal with the linguistic analysis of the persuasive strategies and Covid-19 discourse in different genres and text types from various linguistic perspectives and frameworks.

Based on scholarly and research studies on rhetoric, pragmatics, discourse analysis and related fields, Mulholland (2005) compiles and lists a great number of common persuasive strategies, accompanied with a descriptive account and practical examples for each one. The collection includes various persuasive strategies, for example, repetition, metaphor, rhetorical questions, proverbs, quotations, comparison, emphasis, euphemism, exemplification, and intonation. The significance of this study lies in its attempt to offer a comprehensive coverage of persuasive strategies either in speech or writing used in public life, which can be taken as a stepping stone for researchers working on persuasive strategies. However, it cannot be guaranteed that this collection includes all possible strategies used to persuade others since it derives its findings from certain text types in one language, namely, English.

A wide variety of studies has addressed persuasion from the perspective of pragmatics, particularly, speech acts theory (e.g. Taufik et al., 2014; Altikriti, 2016; Alkhibrash, 2016; Ghazani, 2016; Ponton, 2017; Alemi et al., 2018; and Soedjarwo, 2020). They report that various speech acts can be used to realize persuasion, namely directives (e.g. requests and advisories) commissives (e.g. promises and threats), constatives (e.g. assertives and informatives), and acknowledgments (e.g. compliments and thanking). However, their major focus is placed on the identification of speech acts rather than accounting for the linguistic 
strategies of persuasion. From a sociolinguistic perspective, Al-Khatib (1994) investigates the language of persuasion in Jordanian society. His study is limited to three modes of persuasion: emotional appeal, argument, and trustworthiness. It maintains that Quranic verses, wisdoms, and proverbs are commonly crucial persuasive devices in the change of one's beliefs, attitude, and orientation.

Numerous studies focus on persuasion in certain genres or text types such as advertisements, health campaigns, magazines, academic writing and political speeches (e.g. Crismore \& Farnsworth, 1989; Crismore et al. 1993; Zheng, 2000; Virtanen \& Halmari, 2005; Dafouz-Milne, 2008; Issa, 2017). For example, Issa (2017) examines the persuasive functions of politeness strategies in Jordanian print advertisements that aim at persuading customers of their products. His study finds that the advertisements employ largely positive politeness strategies to build a good rapport with the customers. Among these persuasive strategies are intensification, praising, offering, exaggeration, comparisons, and repetition. Similarly, Romanova and Smirnova (2019) explore persuasive techniques in English advertisements such as politeness, praising, repetition, and quotations. In a different genre, Rudolf von Rohr (2017) investigates persuasive strategies in online public health campaigns to motivate smokers to quit smoking. The findings show that a wide range of techniques is used to involve readers in the campaigns and make them align with the intended message, mainly advising, warning, personal pronouns, praising, terms of address, and rhetorical questions. She stresses that the employment of such linguistic devices makes the health message to cease smoking more appealing to the reader. In relationship advice articles in women's English magazines, Lulu and Alkaf (2019) find that different strategies (e.g. pronouns, imperatives, modality, questions, intimate expressions, and informal language) serve to convince readers to accept the given advice. They point out that these strategies display the writer as a friend more than as an expert, which helps minimize the social distance between the writer and his readers and capture their attention to approve what is advised.

While Zheng (2000) examines how language is employed in political discourse to gain public support, Hyland (2005) explores how discourse practices (e.g. citation, self-mention, personal pronouns, and directive speech acts) contribute to persuasion of academic writing. Zheng's findings show that the deployment of inclusive pronouns, quotations and citations helps politicians enhance the effectiveness and persuasiveness of their argument. Likewise, Hyland's study finds that the use of pronouns and citations helps the writer construct an effectual justification and support for his argument and enhance his credibility. It points out that the use of these strategies is not simply stylistic but plays an effectively persuasive role in academic writing

Though persuasive strategies have been extensively explored in different genres and text types, few studies are concerned with persuasive strategies in government discourse. Ho (2016) explores the Hong king government's discursive attempts to persuade the public to accept its policy reforms, focusing on the use of interactional and interactive metadiscourse (e.g. hedges, boosters, attitude markers, and self-mentions) to actualize the persuasive attempts. A more recent study is carried out by Khajavi and Rasti (2020) in American context, who investigate the use of persuasive and rhetorical strategies from Critical Discourse Analysis. Unlike many studies, Charteris-Black (2011) devotes his study to one persuasive strategy, namely, metaphors in the language of political leaders used to persuade the potential followers that they and their opinions can be trusted. He argues that metaphor is effectively used for communicating the speaker's political views and policies, evoking his audience's emotional response and positive and negative representations of supporters and opponents, respectively. The persuasive process is "a multi-layered discourse function" since it is the product of a composite interplay between intention, context, and linguistic choice (Charteris-Black, 2011, p.51). 
Since the outbreak of the Covid-19 pandemic, a growing number of studies on the language of Covid-19 discourse from various linguistic perspective and frameworks have been carried out (Nor Fariza Mohd Nor \& Adlyn Syahirah Zulcafli, 2020; Katermina \& Yachenko, 2020; AlAfnan, 2020; Simatupang \& Supri, 2020; Haddad \& Montero-Martinez, 2020). However, it seems that these studies reviewed for the purpose of the present paper do not pay attention to the persuasive language in Covid-19 context.

To conclude, the review of the previous studies reflects that persuasive strategies have been extensively approached from various linguistic perspectives and frameworks in different genres and text types. However, it reveals that they have been underexplored in Covid-19 discourse. Therefore, the present investigation is one of the first studies that seeks to offer an analysis of persuasive strategies in Covid-19 context, drawing on discourse analysis and pragmatics. In this paper, we will examine the strategies used by Jordanian government's officials in their media interviews on TV and radio to persuade the public of its policies to fight the Covid-19 pandemic.

\section{METHODOLOGY}

The data for the present study were obtained from TV and radio interviews with the Jordanian government's officials. These interviews are concerned with the Covid-19 situation in Jordan and other related matters, released between March and August 2020. They are drawn from local media sources, namely AlMamlaka TV, Jordan TV, Roya TV, and Hala Radio, which are prominent and most popular in Jordan (Ipsos, 2020). The researcher scanned thoroughly the respective sources on their official Facebook pages to extract the interviews. The interviews were manually searched and collected. A larger corpus of 155 interviews was initially compiled, from which a sample was randomly selected (13 interviews were randomly selected from each online source). The rationale beyond selecting this small scale corpus is that it can be manually handled by the researcher, especially in discourse studies (Angermuller, 2015; Alkhawaldeh, 2018). The ensuing corpus consists of 52 interviews, ranging approximately from 15 to 25 minutes for each. This variance in time duration of the compiled interviews does not diminish the quality of the analysis since this study is a qualitatively oriented research, not quantitatively.

To ensure the representativeness of the data that the corpus represents adequately the issue in question and its findings can be generalized (Biber, 1993), the interviews were compiled from different media sources (all of them are neutral outlets except for Jordan TV, which is pro-government), with different officials to avoid individual language idiosyncrasies (e.g. prime minister, ministers of health and labor, and media spokespersons of ministries and government institutions), and at different occasions and times (extending from the outbreak of the virus in Jordan in March to August 2020).

Each interview was separately treated and painstakingly listened to several times searching for the occurrence of the relevant strategies. Due to the small size of the sample, we presumed that any strategy to be shortlisted had to occur at least 3 times in order to be taken as worthy of note.

Identification and analysis of persuasive strategies lie at the heart of the present paper. To uncover and analyze the linguistic strategies used in the corpus to persuade the audience of complying with the government's policy, an eclectic theoretical framework is employed. Following Fairclough (1995) and O'Keeffe (2006), media discourse (particularly interviews) can be best studied through a richly eclectic approach that integrates and draws on discourse analysis, pragmatics, and corpus analysis, where one approach may not help investigate it adequately. While discourse analysis helps us understand certain features and patterns operating within the persuasive discourse, pragmatics helps also account for the forms and 
functions of persuasion in its actual setting. Methodologically speaking, a corpus approach adds to the analysis of persuasive strategies by allowing us to scrutinize the totality of the data, identify consistent patterns of use, and give quantitative findings.

As a first step, the strategies are identified and listed, based on the operational definition given above. While the study operates generally within the domain of pragmatics and discourse analysis since it addresses the language of persuasion in discourse and context, it draws for analysis on the related studies on persuasion reviewed for the purpose of the study. Most importantly, the study relies heavily on Mulholland (2005) on the grounds that his work provides a comprehensive collection of persuasive strategies drawn mainly from numerous studies on rhetoric, pragmatics, and discourse analysis. The study employs his definitions and description of persuasive strategies to identify their occurrence in the corpus under investigation.

In the analysis section, all examples are drawn from media interviews with Jordanian government's officials. Every strategy is provided with illustrative examples, where they are given in their original language, namely, Arabic, followed by their English translation. All translations are mine and they are verified for accuracy and correctness.

\section{FINDINGS AND DISCUSSION}

This section will report and interpret the main findings of the present study. In the corpus, six linguistic strategies were observed to be commonly used by the government officials to persuade the Jordanian public to accept the Covid-19 related policies prescribed by the government to curb the pandemic. These strategies are metaphor, repetition, self-praising, the pronoun "we", warning, and religious quotations. With the exception of the pronoun "we", the strategies identified in the present corpus are listed in Mulholland's collection (2005). Each one of them will be discussed individually in detail in the following subsections.

\section{METAPHOR}

As a salient feature of language, metaphor is a figure of speech that transfers an attribute associated with one thing to another. The use of metaphor is seen as a major persuasive device that guides the addressee to understand and react to a public issue (political, social, and economic, etc.) in a certain way (Mulholland, 2005). Some scholars assert that messages containing metaphors yield greater attitude change than do messages without metaphors (Schmidt \& Kess, 1984; Charteris-Black, 2011; Perloff, 2017).

Many metaphoric instances (with 55 occurrences) were found in the corpus to serve a persuasive strategy in the government discourse on the Covid-19 pandemic in Jordan. We will focus on war metaphors as they pervade the language of the corpus. The analysis demonstrates that the government officials employ extensively the war language when addressing the public regarding its policies to deal with the current pandemic.

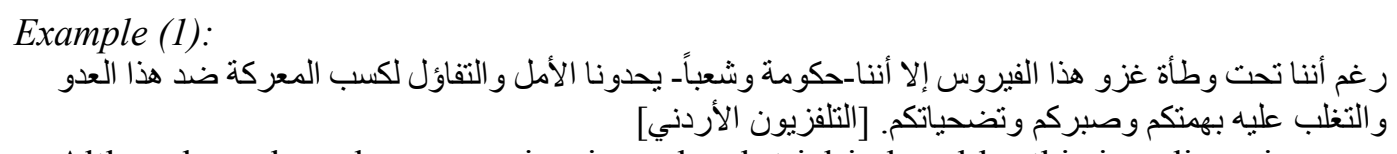
Although we have been experiencing a harsh trial induced by this invading virus, we the government and the public are filled with hope and optimism to win the battle and defeat this enemy, with your assistance, patience, and sacrifice. [Jordan TV]

Example (2):

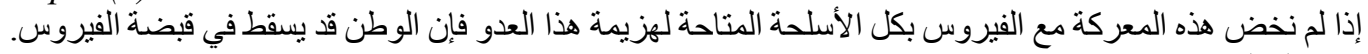


If we didn't fight the battle against the virus with all potential weapons, the homeland will be fallen into the virus's grip. [AlMamlakah TV]

\section{Example (3):}

$$
\begin{aligned}
& \text { و اجبنا جميعا أن نقف يد واحدة على قلب رجل و احد ونلتزم بإجر اءات الحكومة المتعلقة بالحظر و الاغلاقات ولئات وخاصة }
\end{aligned}
$$

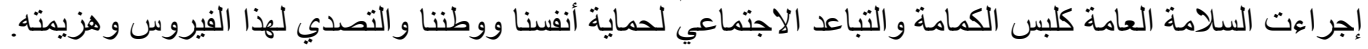

$$
\begin{aligned}
& \text { [قناة المملكة] }
\end{aligned}
$$

We have to stand united, with one goal in our heart, and adhere to the government measures concerning lockdown and curfew especially public safety measures such as mask-wearing and social distancing to protect ourselves and our country and combat and defeat the virus. [AlMamlakah TV]

In the corpus, a wide variety of war-related expressions were used, especially, حرب

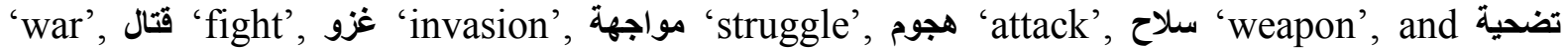
'sacrifice'. This shows that through martial metaphors the government frames the issue of the virus as a war in which two opposing sides are involved. As seen in Examples (1), (2), and (3), while the first side is the virus framed as a foreign enemy invading the country, the other one is the government and the public, who are in a position of fighting against the enemy "the virus" to protect the country. Such a metaphoric usage evokes a vivid image of a real war in the minds of the public that needs power, assistance, sacrifice, and patience to win the war. That is, it is like a military confrontation between Jordan (the government and its people) and the virus in which Jordanian citizens have to fight by the government's side and defeat the opponent. The government employed the war-related expressions and the military metaphor to prompt the public to accept and trust its policy to confront the virus and control its spread, which enhances the government arguments' persuasiveness.

In line with Sontag (1989) that the DISEASE IS WAR, the analysis demonstrates that Covid-19 is metaphorically characterized in the corpus as invading the society and efforts to face it is a war, a struggle, and a fight. It has been asserted that military metaphors are regularly adopted in the discourse that tackles disease, which mobilizes people to fight against a common threat (Chiang \& Duann, 2007; Sexton, 2016; Hons, 2020).

As shown in the above examples, the government employed metaphorical linguistic choices to persuade the public to comply with its policies to contain the virus and avert its consequences on health and economy. More specifically, the presentation of the virus as a dangerous enemy helps convince the target audience of the seriousness of the situation and importance of adherence to the respective procedures, despite they may have harsh impacts on their daily activities.

Based on the findings, it can be stated that the metaphorization of the conflict with the virus is enunciated here as a state of fact, which makes the government position effective in realizing persuasion. The frequent use of martial metaphors (military-related metaphors) by the government officials creates an association in the public mind between the virus and a military confrontation in which two sides are involved: the government as well as the public versus the enemy "Covid-19". This conflict frame is not merely identified by the two sides in a polar opposition but also by what is at stake: the country, as seen in Example (2). It also indicates that what the government does (e.g. imposing curfew, lockdown, mask-wearing, and social distancing) to fight the enemy "the virus" is not intended to harm the public but to protect them, as shown in Example (3). Moreover, it puts the public in a position to help and cooperate with the government in protecting the country and winning this war, despite the potential enormous influence of such policies on different walks of life.

Thus, through the use of metaphor, the traits associated with war as a military action are transferred to the Covid-19 situation in Jordan. Such a metaphorical representation is 
compelling and affective in the persuasive process since it facilitates understanding the danger of the virus by converting abstract thoughts into concert ones. This persuasive strategy of metaphor at work in the corpus insists on the necessity of defense against the virus portrayed as an invading enemy by calling for Jordanian citizens' awareness and participation to comply with the safety and health measures issued by the government.

\section{REPETITION}

As a key feature of oral communication, repetition is an important means in persuasion used generally to foreground certain aspects of the speaker's argument, which are intended to be particularly focused on and memorable (Gadd, 1999). It has been stressed that a public speaker should reiterate any desired policy or idea many times to assure his supporters in their own beliefs and get others convinced of it (Pedrini, 2017). Repetition, Mulholland (2005) points out, is a noticeable act in discourse that can be an aid to understanding the topic being represented. In rhetorical tradition, the strategy of repetition aims mainly at implanting the speaker's messages firmly in the addressee's memories, therefore, it has been drawn on by orators for its powerful and persuasive impact on the audience (Fahnestock, 2011).

Repetition provides recipients with further opportunities to consider the merits of the intended message, motivating them to conform to (Petty \& Cacioppo, 1986). Generally speaking, repetition can be instrumental in reinforcing the regard for the speaker' views and boosting its cogency and incisiveness. In our study, this persuasive strategy is used in the sense of repeating the same words, phrases, or sentences, which is technically called 'lexical repetition'.

The examination reveals that repetition serves to increase the substance of the speaker's message and draw the audience's attention to it. As a persuasive technique in the corpus, repetition was frequently employed by the government officials to sway the public into diligent compliance with the Covid-19 protocols to curb the pandemic. The presence of repetition enhances the public awareness about the risk of the virus and the necessity of its avoidance through compliance with the safety and health guidelines, rendering the intended message more effective, powerful, and persuasive.

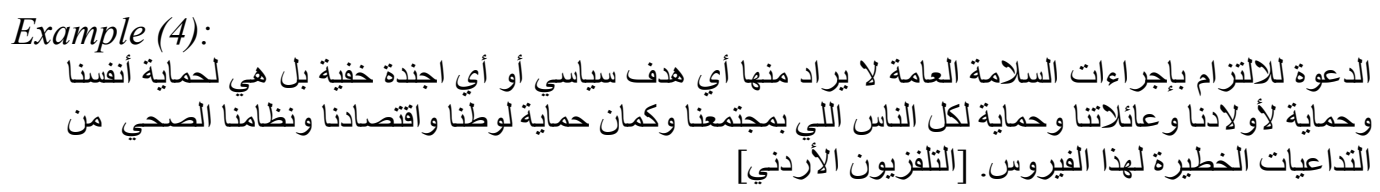

Calling for compliance with public safety measures is not intended for any political goals or other hidden agendas but protecting ourselves, (and protecting) our children, and families, and (and protecting) others within our community. It also protects our homeland, economy, and health system from the severe consequences of the virus. [Jordan TV]

In Example (4), the word حماية 'protection' is noticeably repeated four times (in the Arabic version) to highlight the benefit and necessity of adhering to the public health and safety measures for the Jordanian community. As a way to obtain the desired influence on the Jordanian masses, this repetition as seen in Example (4) places a greater weight on the sole rationale of the government's safety precautions, reassuring the public that these precautions are prescribed for the safety and protection of the country and its people from the coronavirus not for the government' agendas. It also motivates listeners to help and support the government in curbing the pandemic as the protection of Jordan from Covid-19 is a joint obligation and shared responsibility. 


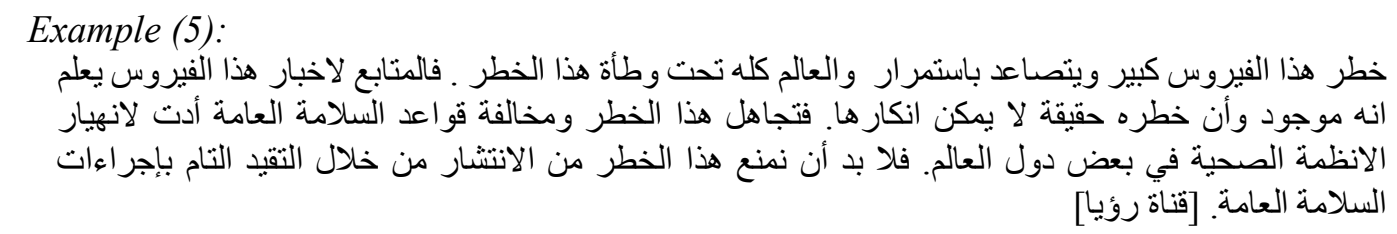

Danger of the virus is enormous and rapidly increasing. This danger has affected the entire world. People who are watching and reading news about the virus know that it really exists and its danger is an undeniable fact. Ignoring this danger and flouting the public health and safety measures resulted in the collapse of some countries' health system. So we should prevent this danger from spreading by strictly adhering to the public safety measures. [Roya TV]

In Example (5), the speaker used repeatedly the word خطر 'danger' (five times), which emphasizes and directs the listeners' attention to the seriousness of the coronavirus, whose potential consequences should be averted. Through repeating the word خطر 'danger', two main goals can be concurrently actualized to persuade the public of unwavering compliance with the preventive and protective regulations: to stress the existence of the virus and to increase the public awareness of its dire consequence. This is because some people are reported to be either skeptical about the existence of the virus or about its severity. Therefore, the repetition strategy reinforces the fact that Covid-19 does really exist and it poses an impending danger to the Jordanian community, galvanizing them to take the necessary precautions.

\section{SELF-PRAISING}

When the speaker praises a person, an attitude, or a proposition, he implicitly invites the listeners to admire or accept what he says. Praising is generally seen as one manifestation of positive evaluation that can be employed as an effective tool in persuasive discourse (Mulholland, 2005). As a speech act, self-praising is practiced by speakers to promote themselves during their interaction with each other $(\mathrm{Wu}, 2011)$. The importance of selfpraising lies in its multi-functionality in the persuasive processes. On one hand, it enhances the credibility and capability of the entity being praised. On the other hand, it supports certain actions or attitudes and refutes or undermine the opponents' counterclaims. Self-praising is used here in the sense that the government builds a positive self-image to make a favorable impression on the audience.

A closer look into the corpus reveals that the use of self-praising by the government is common as it has come under fire many times because of claims of incapability and failure. The primary goal of self-praising at issue is to influence the public attitude in favor of the government. In the corpus, it is self-evident that the government communicators repeatedly keep on extolling the virtues of the government, highlighting in particular its achievements and capability to curb the pandemic. In so doing, the government is the subject and object of praising.

The examination yields that three distinct patterns of self-praising were utilized to realize persuasion: focus on achievements, morality and capability. These patterns are not accidental but strategically used to effectively bring about its core purpose- to persuade the public to gain their compliance.

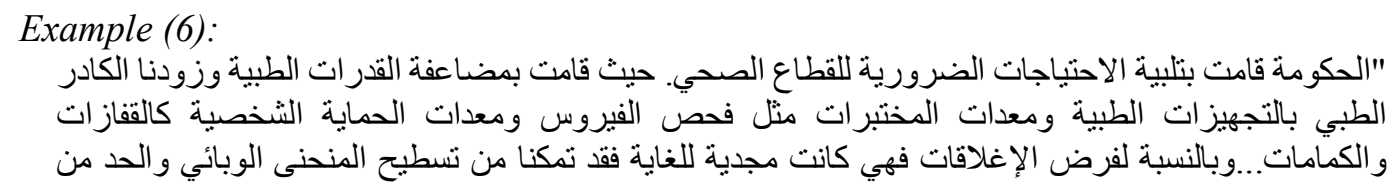




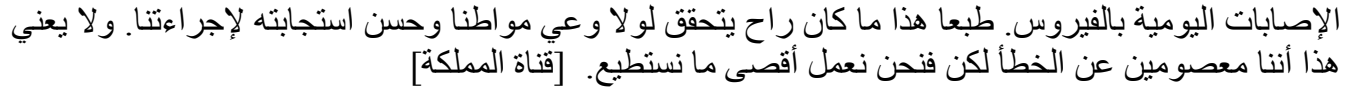

The government met the pressing needs of the health-care sector. It doubled its medical capabilities and provided healthcare workers with medical facilities and laboratory supplies and personal protective equipment e.g. gloves and face masks...as for the imposition of lockdowns, it has been greatly fruitful. We managed to flatten the curve and limit daily virus cases. Of course, this wouldn't have been possible without the citizens' awareness and positive response to our measures. However, this does not mean we are infallible but we do our best. [AlMamlakah TV]

The first pattern of self-praising is to talk of factual achievements and efforts held to be commendable and admirable. As seen in Example (6), the speaker embarked on reporting what the government have done to handle the Covid-19 pandemic e.g. doubling medical capacities, ensuring medical facilities and supplies, and flattening the curve of daily confirmed positive cases. Seemingly, the government is aware that the focus on such achievements that greatly concern the public is vital in its persuasive intention since Jordanians are extremely perturbed about the government's handling of the health and economic impact of the pandemic more than any other issues.

It is worth mentioning that one's self-praising of one's achievements may backfire if not properly delivered. Not to be perceived as bragging, the speaker qualified his prior assessment by claiming that what the government have done is not infallible but they did everything possible and these achievements would not have been possible without the citizens' awareness and positive response. That is, the speaker latched the subsequent follow-up statement onto his praising of the government's achievements to mitigate any potentially negative consequences of its force. Due to Jordanian cultural norms that cherish modesty, this attempt to act modestly in commending achievements makes the message more persuasive and acceptable.

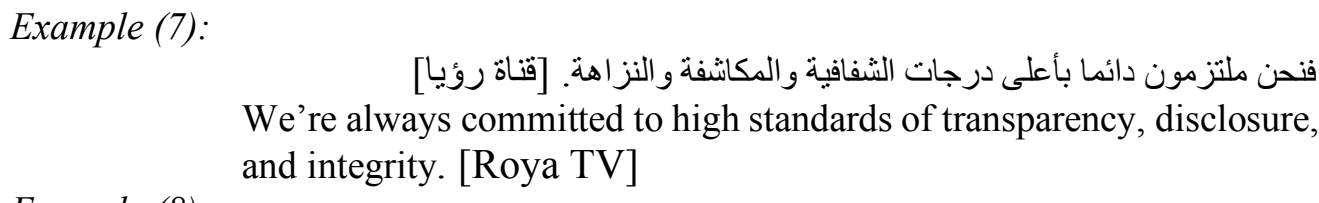

Example (8):

$$
\text { الحكومة تصرفت بحكمة وعقلانية عندما أغلقت الجامعات والدارس. [ راديو هلا ] }
$$

The government has acted with wisdom and rationality when closing universities and schools. [Hala Radio]

Another pattern of self-praising for persuasive purpose is the focus on the moral attributes of the government. In the corpus, an array of positive qualities were noticeably used

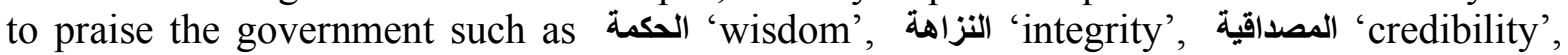
الثفافية 'transparency', العمل الجاد 'open-mindedness', and 'الانفتاح 'hard-working'. As seen in Example (7), the speaker reinforces that the government is highly committed to honesty and transparency, which can be taken as a strategy to persuade the public of the government' credibility. In Example (8), the speaker commends the government for its wisdom and rationality with regard to closing schools and universities to limit the spread of the virus. This prominent deployment of the government's moral merits is intended by the speakers to have the public deem the government in the same positive way and trust and appreciate its efforts to curb the pandemic.

The last pattern of self-praise in the corpus is the focus on capability (e.g. competence, proficiency, and preparedness) to manage conditions and events to effect a desired end. The 
government officials employ a wide variety of lexical options that belong to the semantic field of capability (the power or ability to do something) to produce a positive self-presentation, for example, قادرون 'capable', على أتم الاستعداد 'well-prepared', مدربون 'well-trained', الخبرة 'expertise', and أصحاب كفاءة 'proficient'.

This obviously demonstrates that the government is positively represented as being capable to deliver the required level of performance that fulfills the mandated objectives. This abundant use of the capability-related expressions implies that the government seeks to gain the public confidence (especially those in a panic about the virus) regarding its capacity to cope with the crisis. The rationale for the use of this pattern may be that the government has been criticized for its inept handling of the situation.

In short, the government appeals to the self-praising technique to reinforce the persuasive power of its argument directed to the public and undermine the justifiability of the opponent's claims. As a persuasive strategy, the use of self-praising in the corpus is not accidental but appears rather to be strategically designed and employed to enhance the public persuasion towards the government's performance during the Covid-19 pandemic. It also gets the public to perceive and acknowledge the government's trustworthiness to align themselves with its policies to fight Covid-19.

\section{THE PERSONAL PRONOUN "WE"}

It has been shown that pronouns are of paramount importance in the process of persuasion. As a persuasive strategy, the choice of personal pronouns has been characterized as a clever and subtle tool to influence the thinking of the audience, penetrating successfully throughout the speech (Virtanen \& Halmari, 2005). Nevertheless, Mullholand (2005) does not include the use of pronouns in his collection on persuasive tactics though their persuasive force has been proved to be effective by numerous studies (Wilson, 1990; Pennycook, 1994; Hyland, 2001; Partington, 2003; Íñigo-Mora, 2004; Harwood, 2007).

The focus of this section is limited to the persuasive use of the pronoun "we" due to its high frequency (with 88 occurrences) in comparison with other pronouns such as "I" and "you", which were observed to have a very low presence in the corpus (with total frequency of 14 times). The pronoun "we" can be either inclusive or exclusive: while the former includes the speaker and the audience and possibly others, the latter includes the speaker and others but not the audience (Levinson, 1983).

The analysis reveals that the government officials utilized extensively the pronoun "we" in their attempt to persuade the public of their policies pertaining to the Covid-19 pandemic. Both forms of the pronoun "we" were found to occur in the corpus. However, the inclusive "we" appeared to occur much more frequently (with 58 occurrences) than its exclusive counterpart (with 30 occurrences). This is consistent with other studies that find that the inclusive "we" is the most commonly used among the personal pronouns as a key persuasive feature of oral discourse (Zheng, 2000; Virtanen \& Halmari, 2005).

To start with the inclusive "we", its high distribution in the corpus reflects that the government rests heavily on this persuasive strategy to gain the Jordanians' allegiance and support and to have them believe that the government's decisions are the right ones.

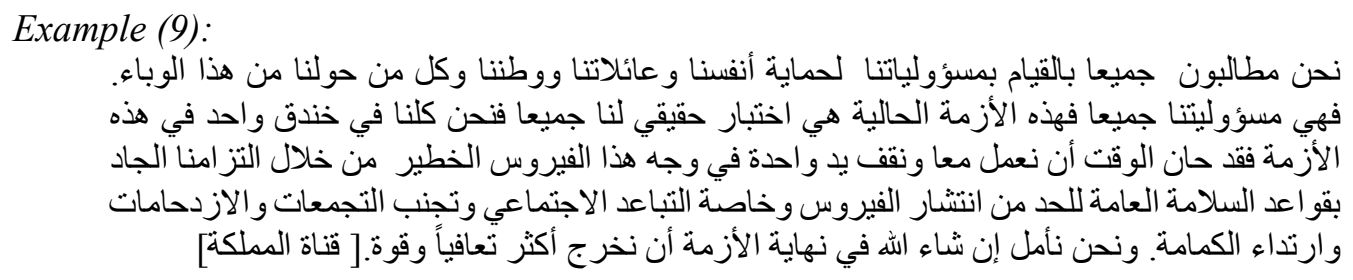


We all should take our responsibilities to protect ourselves, our families, our homeland, and those around us from the Covid-19. It is the responsibility of all of us. The ongoing crisis is a real test to all of us as we all are in the same boat. It is time to work and stand together in the face of this formidable coronavirus by strict adherence to the public safety measures to limit the spread of the coronavirus, particularly, social distancing, avoiding crowds and gatherings, and face mask wearing. Hopefully, at the end of this crisis, we will emerge more resilient and stronger. [AlMamlakah TV]

As Example (9) shows, the speaker reinforces that the implementation of the safety measures to contain the Covid-19 pandemic and its grave consequences is a common responsibility of all Jordanians: the government and the citizens. By making use of the inclusive "we", the speaker intends to engage the audience in the battle against the virus, which is not only the government's responsibility but it is the shared responsibility of every citizen. Indeed, this inclusive "we" helps the speaker make a favorable impression of involvement and intimacy on the audience that they and the government should join hands to defeat their public ferocious enemy, the coronavirus. It, thus, creates an atmosphere of togetherness and belonging within Jordanian society by sharing and defending their national issues.

According to the findings, the inclusive "we" is extensively and systematically used by the government officials to bolster its function as a persuasive strategy to sway the public opinion in favor of the government's attitude. This is clearly illustrated in Example (9) (Arabic text), where the inclusive نحن 'we' and its grammatical variants occurred 12 times in one single excerpt. This observation is in line with the finding of other studies (e.g. Partington, 2003; Zheng, 2000) that the excessive use of the inclusive "we" is effectively useful in some circumstances to have the audience believe that any decisions are not only one individual's responsibility.

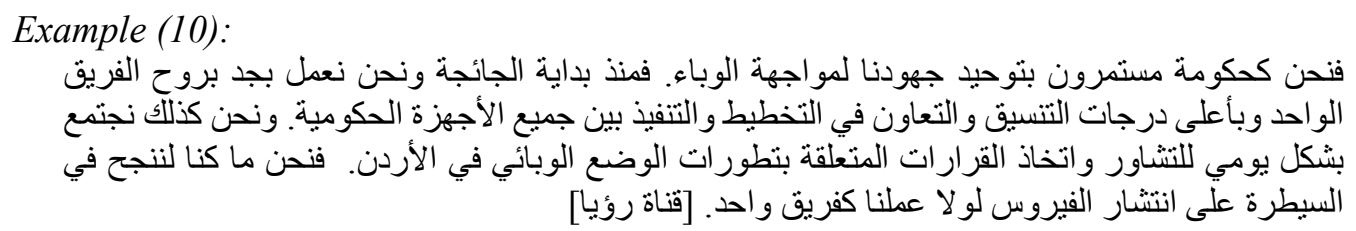
We, as the government, continue our united efforts to encounter the pandemic. Since the outbreak of the pandemic, we have been working vigorously in the spirit of teamwork, with optimal coordination and collaboration in planning and implantation between all government bodies. And, we hold daily meetings concerning the epidemiological developments in Jordan. We could not have successfully controlled the spread of the virus without working as one team. [Roya TV]

The exclusive "we" and its grammatical variants are relatively less frequent in the corpus, which may be due to the focus of the government on assimilating itself into the audiences and engaging them actively into the efforts to fight the pandemic through employing the inclusive "we". As seen in Example (10), the speaker used the exclusive "we" that refers to the whole government to incentivize the public to count the government as one body or team that works harmoniously together to manage the crisis. This may be ascribed to some alarming news circulated on social media about the lack of coordination in planning and implantation among the government ministries in tackling the pandemic that contributes to the Covid-19 causality toll.

To conclude this section, the pronoun "we" is used in the corpus to serve inclusive and exclusive functions, where it is extensively deployed as a strategy to persuade the public. The inclusive "we" is utilized by the government officials to promote a sense of responsible togetherness and intimacy with listeners to engage them in the government's measures to 
handle the Covid-19 pandemic. The exclusive "we" serves to get the public to view the government positively that they work in the spirit of teamwork and are strongly united in their efforts against the pandemic.

\section{WARNING}

Warning is a crucial speech act in communication since it often plays a key role in helping others to avoid potentially undesirable consequences e.g. injuries, illnesses, and losses (PérezHernández, 2020). Warning is quite common in persuasive communication in which either something undesirable is associated with negative outcomes or something desirable is associated with the avoidance of negative outcomes (Higbee, 1969). Generally speaking, the primary function of warning is to inform or make someone aware of a potential harm or danger, guiding him to the rational course of action.

A close look into the data reveals that the speech act of warning is frequently employed by the government officials as a persuasive tool to alert the Jordanian public through focusing on the grave consequences of failure to align themselves with the government's Covid-19 protocols. Interestingly, it is observed that some warning instances in the corpus are associated, to some extent, with fear-arousing and threatening to heighten the level of persuasive power of warning messages. This can be justified on the grounds that messages that arouse greater fear are generally more persuasive (O'Keefe, 2002). For example, the speaker in Example (11) below warned the public against flouting the safety and health regulations by threatening with penalty of fine and imprisonment.

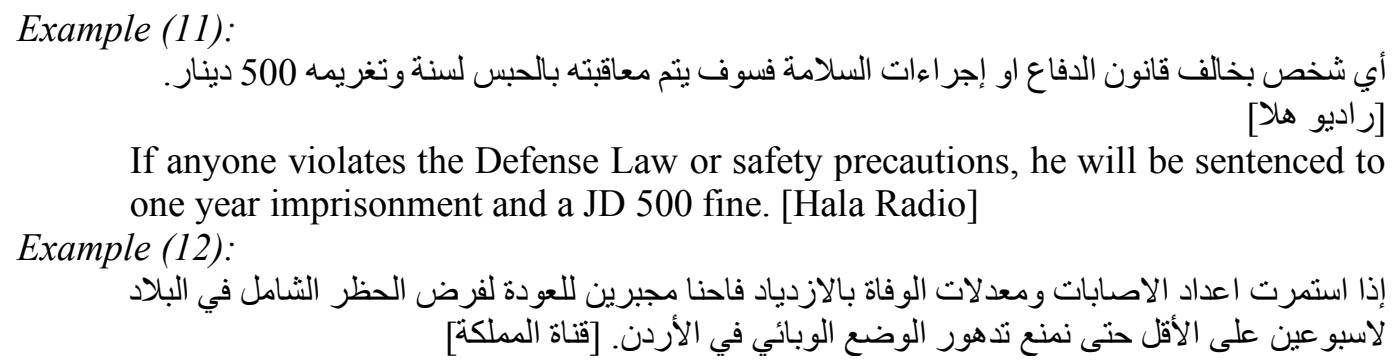

If the number of infection cases and death toll continues to surge, we may be forced to re-impose a full lockdown for at least two weeks across the country in order to prevent deterioration of the epidemiological situation. [AlMamlakah TV] Example (13):

$$
\begin{aligned}
& \text { ونحذر من أن عدم التز امنا بإجر اءات السلامة العامة فسوف يدخلنا منطقة الخطر بارتفاع حاد لمعدل الاصيابات }
\end{aligned}
$$

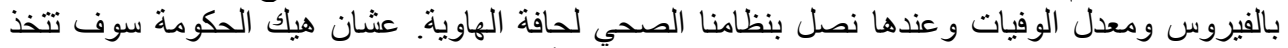

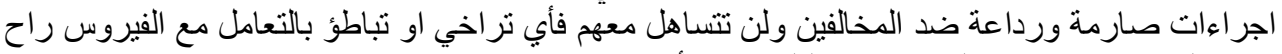

$$
\begin{aligned}
& \text { يكون إله عو اقب وخيمة علينا جميعا. [التلفزيون الأردني] }
\end{aligned}
$$

We warn that failure to comply with public protective measures will give rise to entering "danger zone", with exponential upsurge of coronavirus infections and death toll, pushing our health system to the brink of collapse. So, the government will not relent and will take strict and deterrent measures against people violating the curfew. Any leniency or slowdown in handling the virus will lead to very dangerous repercussions. [Jordan TV]

In Examples (12) and (13), to persuade the target audience of the importance of adherence to the government' Covid-19 protocols, the speaker informed the audience about the imminent dangers of not abiding by the health and safety regulations such as the rise of infection cases and death toll and the collapse of health system. These dangers normally arouse the public's fears for motivating them to ward off the hazard by doing the right thing. The use of lexical choices related semantically to "fear-mongering" or "fear-arousal" such as الوفاة 
'death', العدوى 'infection', انهيار 'collapse', and عقوبة 'penalty' enhances the persuasive force of warning. In some cases in the corpus as seen in Example (13), the speakers made the warnings explicitly stated through using the Arabic verb يحذر and its synonyms 'to warn', which turns the addressee's attention to perceiving what is given as a serious warning.

Though the speech act of warning does not appear in a standardized format because speech acts are generally defined by their pragmatic function rather than their linguistic form (Muschalik, 2018), the corpus displays that the preferred syntactic form to realize a persuasive warning speech act is conditional structure (if -clause) as shown in Examples (11) and (12). The use of this construction seems to be effectual in the persuasiveness of the warning strategy since it places the addressee at a crossroads between two scenarios either to manage to defeat the coronavirus by complying with what the government calls for or to lose the battle and hence the collapse of the country.

\section{RELIGIOUS QUOTATIONS}

Religion has power to affect, in myriad ways, people to behave and think in a certain way to cope with life's demands (Donahue \& Nielsen, 2005). The use of religious texts plays a pivotal role in convincing followers do what is right and avoid what is wrong. These texts are made authoritative by repeated use and acceptance by culture, and thereby deemed to be truths to be heeded. Often in any oppositional interaction, speakers tend to supply support for their views or for others by showing that a reputable source or figure also holds them or by using a generally accepted epigram as a useful tactic to persuade the addressee (Mulholland, 2005).

In the present study, religious quotations are drawn from the Holy Quran and Prophet Muhammad's sayings employed by the speaker for persuasive purpose. Muslim Jordanians believe that the Quran and the prophet's sayings are the most sacred and authentic sources of knowledge and teachings that should be revered and heeded, considering them as divine guidance for conduct in daily life. Islam takes into account humankind's health and well-being and the methods of safety and health protection and prevention are rooted in its teachings.

Based on the analysis, this strategy is the least frequently used in comparison with other strategies (with 10 occurrences), which may be due to the focus on the coronavirus as a medical matter rather than religious one. Appealing to religious quotations was mostly used by the minster of Islamic affairs and the staff of the ministry. Government officials utilized the weight of the cultural authority of religious quotations to support their argument, and so inclines the listener to accept it.

It seems obvious that the deployment of religious quotations that legitimizes the government's decisions on circumspection reinforces the persuasive force of the speaker' argument and induces his target audience to collaborate and align with the prescribed measures for keeping the country safe and healthy. Its primary function is to convince the public of the importance of adherence to the government's Covid-19 protocols and to give the speaker's message more credence that what he argues for is not a personal opinion but inherent part of religious belief and commitment.

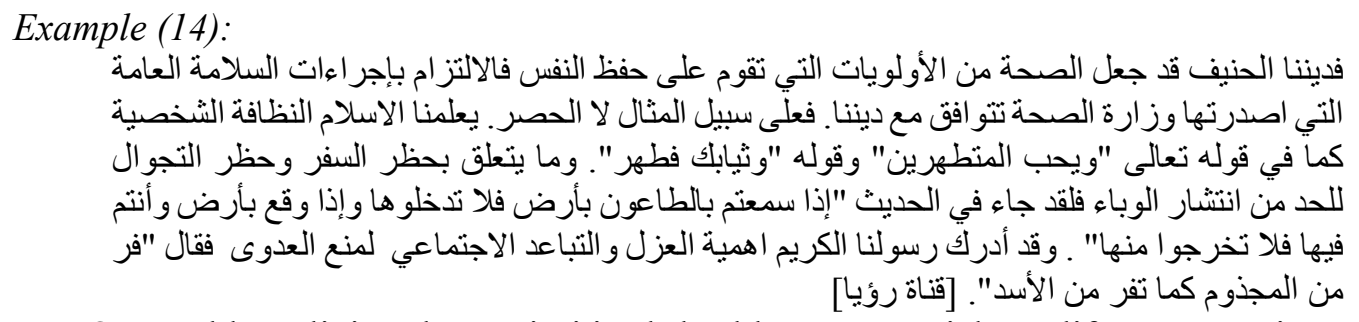

Our noble religion has prioritized health as essential to life preservation. Therefore, adhering to safety and health measures issued by the health authorities 
are congruent with our religion. To mention a few, Islam teaches self-hygiene as Allah said "He loves those who keep themselves clean and pure" and "and keep your clothes clean". For travel bans and lockdown in places infected with disease to stop its spread, the prophet said "If you hear of an outbreak of plague in a land, do not enter it; and if the plague breaks out in a place while you are in it, do not leave that place". The prophet also recognized the importance of quarantine and distancing to prevent infection when he said "one should run away from the leper as one runs away from a lion". [Roya TV]

In Example (14), the speaker called on Jordanians to abide by all health and safety precautions such as self-hygiene, quarantine, distancing, and lockdowns. To support his argument and persuade the public of the importance of these measures, he highlighted that the government's Covid-19 protocols are congruent with Islamic teachings through incorporating some religious quotations pertinent to these protective practices. For example, the minister pointed out that self-hygiene is mentioned and recommended by Islam, quoting two Quranic verses in this regard that call for cleanliness of body and clothes. These quotations leave impression on the public that what contributes to public well-being is religiously mandatory.

Example (15):

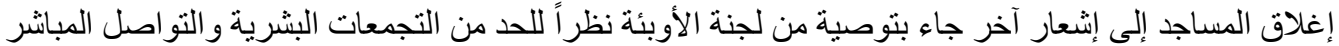

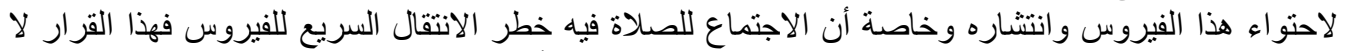

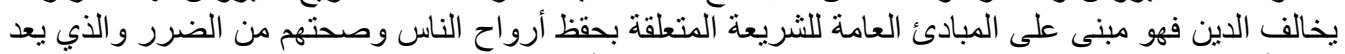

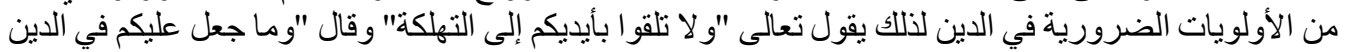

$$
\begin{aligned}
& \text { من حرج". [قناة المملكة] }
\end{aligned}
$$

Closure of mosques until further notice was recommended by the epidemiological committee to limit people contact and gathering to contain the spread the virus, especially, gathering to worship risks rapid covid-19 transmission. This decision does not contradicts Islam because it is based on its general principles pertaining to protection of people's lives and health from harm, which is considered one of the essential priorities in Islam. Allah said "do not throw yourselves into destruction" and said "He has imposed no difficulties on you in religion. [AlMamlakah TV]

In Example (15), to legitimize closure of mosques imposed by the government, the speaker employed some religious quotations from the Holy Quran that underline the flexibility and facilitation of Islamic law to fit Muslims' needs and prohibition of self-harming. Thus, it supports the primary goal of the speaker to convince Jordanians of the correctness of the government' decision and its conformity with Islamic tenants.

\section{CONCLUSION}

In this paper, we have attempted to offer an analysis of persuasion in Jordan's government discourse on the Covid-19 pandemic. More specifically, the intent of the present investigation has been to contribute to a better understanding of the linguistic realizations of persuasion in the government communication to influence Jordanians' public attitude.

For its purpose, the study compiled a corpus from a variety of interviews on TV and radio with the government officials, drawing on an eclectic theoretical framework. The findings demonstrate that the government officials made persuasive attempts by relying heavily on six linguistic strategies used recurrently in the corpus, namely, metaphor, repetition, selfpraising, warning, personal pronoun "we", and religious quotations. They also show that these strategies were designed to persuade rather than to inform the target audience about the government's efforts and policy to combat the coronavirus. Moreover, the results reveal that 
the rationale beyond the respective persuasive strategies seems to win public compliance and cooperation, reassure the public, undermine opponent's counterclaims, and project a trustworthy and praiseworthy image.

The main potential contributions of the current research are twofold. First, it contributes particularly to the existing and growing literature on persuasion by identifying and analyzing the common persuasive strategies, based on empirical data. Second, it contributes to linguistic and non-linguistic studies on Covid-19 discourse by giving more insights into this new area of research. The study is set to trigger further studies on persuasion in particular and other linguistic issues in Covid-19 discourse.

The study intends by no means to be an exhaustive treatment of persuasive strategies. It calls for further linguistic studies to shed more light on persuasion in the Covid-19 discourse as the present study hopefully paves the way for future work on this underexplored area of research.

\section{REFERENCES}

Adam, M. (2017). Persuasion in Religious Discourse: Enhancing Credibility in Sermon Titles and Openings. Discourse and Interaction. 10(2), 5-25.

Alafnan, Mohammad. (2020). Covid-19- The Foreign Virus: Media Bias, Ideology and Dominance in Chinese and American Newspaper Articles. International Journal of Applied Linguistics \& English Literature. 9(1), 56-60.

http://dx.doi.org/10.7575/aiac.ijalel.v.9n.1p.56

Alemi, Minoo., Latifi, Ashkan., \& Nematzadeh, Arash. (2018). Persuasion in Political Discourse: Barak Obama's Presidential Speeches against Isis. Russian Journal of Linguistics. 22(2), 278-291.

Al-Khatib, Mahmoud. (1994). A Sociolinguistic View of the Language of Persuasion in Jordanian Society. Language, Culture, and Curriculum. 7(2), 161-174.

Al-Khawaldeh, Asim. (2018). Discourse Functions of Kama in Arabic Journalistic Discourse from the Perspective of Rhetorical Structure Theory. International Journal of Applied Linguistics and Literature. 7(3), 206-213.

Alkhirbash, Abdulrahman. (2016). Speech Acts as Persuasive Devices in Selected Speeches of Dr. Mahathir Mohammed. International Journal of English and Education. 5 (2), 81103. Retrieved April 28, 2020 from

http://ijee.org/yahoo_site_admin/assets/docs/8.9925443.pdf

Altikriti, Sahar. (2016). Persuasive Speech Acts in Barack Obama's Inaugural Speeches (2009, 2013) and The Last State of the Union Address. International Journal of Linguistics, 8 (2), 47-66.

Angermuller, Johannes. (2015). Discourse Studies. In: James D. Wright, (Ed.). International Encyclopedia of the Social \& Behavioral Sciences (pp. 510-515). Amsterdam: Elsevier.

Beebe and Beebe. (2018). Public Speaking: An Audience-Centered Approach. Boston: Pearson Education.

Berger, L. L., \& Stanchi, K. M. (2018). Legal Persuasion: A Rhetorical Approach to the Science. New York: Routledge.

Biber, D. (1993). Representativeness in Corpus Design. Literary and Linguistic Computing. 8, 243-257.

Charteris-Black, Jonathan. (2011). Politicians and Rhetoric: The Persuasive Power of Metaphor. Palgrave Macmillan.

Chiang, W. and Duann, R. (2007). Conceptual Metaphors for SARS: 'war' between whom?'. Discourse \& Society. 18(5), 579-602. 
Crismore A. \& R. Farnsworth (1989). Mr. Darwin and His Readers: Exploring Interpersonal Metadiscourse as a Dimension of Ethos. Rhetoric Review. 8 (1), 91-112.

Crismore, A., Markkanen R., \& Steffensen, M. (1993). Metadiscourse in Persuasive Writing: A Study of Texts Written by American and Finnish University Students. Written Communication. 10(1), 39-71.

Dafouz-Milne, E. (2008). The Pragmatic Role of Textual and Interpersonal Metadiscourse Markers in the Construction and Attainment of Persuasion: A Cross-linguistic Study of Newspaper. Journal of Pragmatics, 40 (1), 95-113.

Donahue, M. J., \& Nielsen, M. E. (2005). Religion, Attitudes, and Social Behavior. In R. F. Paloutzian \& C. L. Park (Eds.). Handbook of the Psychology of Religion and Spirituality (pp. 274-291). New York: The Guilford Press.

Fahnestock, J. (2011). Rhetorical Style: The Uses of Language in Persuasion. Oxford: Oxford University Press.

Fairclough, Norman. (1995). Media discourse. London: E. Arnold.

Gadd, N. (1999). A Systemic Functional Analysis of a Televised Political Debate before the 1996 Australian Federal Election. Unpublished M.A thesis, University of Melbourne, Melbourne, Australia.

Ghazani, A. Z. (2016). Study of Persuasive Strategies in Selected American Presidential Speeches. International Journal of Humanities and Cultural Studies. 3(2), 631- 647.

Haddad, Amal, \& Montero-Martinez, Silvia. (2020). COVID-19: A Metaphor-Based Neologism and Its Translation into Arabic. Journal of Science Communication. 19(05) https://jcom.sissa.it/archive/19/05/JCOM_1905_2020_A01

Harwood, Nigel (2007). Political Scientists on the Functions of Personal Pronouns in Their Writing: An Interview-Based Study of 'I' and 'we'. Text \& Talk. 27(1), 27-54

Higbee, Kennethe. (1969). Fifteen Years of Fear Arousal: Research on Threat Appeals: 19531968. Psychological Bulletin. 72(6), 426-444.

Ho, Victor. (2016). Discourse of Persuasion: A Preliminary Study of the Use of Metadiscourse in Policy Documents. Text \& Talk. 36 (1), 1-21.

Hons, Emma. (2020). War and imprisonment: A discourse analysis exploring the construction of meanings and realities surrounding COVID-19 within mainstream news media. M.A thesis, the University of Hertfordshire, Hertfordshire, United Kingdom. Retrieved July 20, 2020 from

https://www.herts.ac.uk/ data/assets/pdf file/0009/315999/War-and-ImprisonmentA-Discourse-Analysis-Exploring-the-Construction-of-Meanings-and-RealitiesSurrounding-COVID-19-Within-Mainstream-News-Media-.pdf

Hyland, K. (2001). Humble Servants of the Discipline? Self-Mention in Research Articles. English for Specific Purposes. 20(3), 207-226.

Hyland, K. (2005). A Convincing Argument: Corpus Analysis and Academic Persuasion. In Connor, U. \& Upton, T., (Eds.). Discourse in the Professions: Perspectives from Corpus Linguistics (pp. 87-114). Amsterdam: Benjamins.

Íñigo-Mora, Isabel. (2004). On the Use of the Personal Pronoun We in Communities. Journal of Language and Politics. 3(1), 27-52.

Ipspos. (2020). Ipsos' Jordanian Consumer Sentiment Index Q2 2020. https://www.ipsos.com/en-jo/ipsos-jordanian-consumer-sentiment-index-q2-2020

Issa, Sadam. (2017). A study into Politeness Strategies and Politeness Markers in Jordanian Print Advertisements as Persuasive Tools. Journal of politeness Research. 13(1), 61-87

Johnstone, K. B. (1987). Parataxis in Arabic: Modification as a Model for Persuasion. Studies in Language. 11(1), 85-98. 
Johnstone, K. B. (1989). Linguistic strategies and cultural styles for persuasive discourse. In S. Ting-Toomey \& F. Korzenny (Eds.), Language, communication, and culture (pp. 139157). Newbury Park, CA: Sage.

Katermina, V. and Yachenko, E. (2020). Axiology of COVID-19 as a Linguistic Phenomenon in English Mass Media Discourse. Advances in Journalism and Communication. (8)2, 59-67. https://doi.org/10.4236/ajc.2020.82005

Khajavi, Y., \& Rasti, A. (2020). A Discourse Analytic Investigation into Politicians' Use of Rhetorical and Persuasive Strategies: The Case of US Election Speeches. Cogent Arts \& Humanities. 7(1), 1-15 https://doi.org/10.1080/23311983.2020.1740051

Lee, G. (2005). Persuasion, Transparency and Government Speech. Hastings Law Journal. 56 (5), 983-994.

Levinson, S. C. (1983). Pragmatics. Cambridge: Cambridge University Press.

Lulu, R. A. \& Alkaff, S. N. H. (2019). A Cross-Cultural Study of Persuasive Strategies in Relationship Advice Articles in Women's Magazines. GEMA Online ${ }^{\circledR}$ Journal of Language Studies. 19(2), 15-32.

Mulholland, Joan. (2005). Handbook of Persuasive Tactics. London: Routledge.

Muschalik, Julia. (2018). Threatening in English: A mixed Method Approach. Amsterdam: John Benjamins Publishing Company.

Nor Fariza Mohd Nor \& Adlyn Syahirah Zulcafli. (2020). Corpus Driven Analysis of News Reports about Covid-19 in a Malaysian Online Newspaper. GEMA Online ${ }^{\circledR}$ Journal of Language Studies. 20(3), 199-218.

O’Keeffe, Anne. (2006). Investigating Media Discourse. London: Routledge.

O’Keeffe, Anne. (2011). Media and discourse analysis. In J. P. Gee \& M. Handford (Eds.). The Routledge Handbook of Discourse Analysis. London: Routledge.

O'Keefe, Daniel J. (2002). Persuasion: Theory and Research. Thousand Oaks: Sage Publications.

Parsons, Patricia. (2013). Beyond Persuasion: Communication Strategies for Healthcare Managers in the Digital Age. Canada: University of Toronto press.

Partington, A. (2003). Politics, Power and Politeness. In A. Partington (Ed.). The linguistics of political argument (pp. 124-155). London and New York: Routledge.

Pedrini, Pier Paolo. (2017). Propaganda, Persuasion and the Great War. London \& NY: Routledge.

Pelclova, J., and Lu, W. (2018). Persuasion across Times, Domains and Modalities. In Pelclova, J., \& Lu, W. (Eds.). Persuasion in Public Discourse: Cognitive and Functional Perspectives. Amsterdam: John Benjamins Publishing Company.

Pennycook, A. (1994). The Politics of Pronouns. ELTJ. 48(2), 173-178.

Perelman, Chaïm. (1982). The Realm of Rhetoric. Trans. by W. Kluback. Notre Dame: University of Notre Dame Press.

Pérez-Hernández, Lorena. (2020). Speech Acts in English: From Research to Instruction and Textbook Development. Cambridge: Cambridge University Press.

Perloff, Richard. (2017). The Dynamics of Persuasion: Communication and Attitudes in the $21^{\text {st }}$ Century. New York and London: Routledge.

Petty, Richard E. and John T. Cacioppo (1986). The Elaboration Likelihood Model of Persuasion. In Leonard Berkowitz, (Ed.), Advances in Experimental and Social Psychology (pp. 123-205). New York: Academic Press.

Ponton, Douglas. (2017). Persuasive Farce: Dialogical Pragmatics in the Novels of P.G. Wodehouse. Lingue e Linguaggi. 23 (2017): 195-209. Retrieved April 28, 2020 from http://siba-ese.unisalento.it/index.php/linguelinguaggi/article/view/17452

Porto, Brian. (2020). Rhetoric, Persuasion, and Modern Legal Writing: The Pen Is Mightier. Lexington 
Romanova, I. D., \& Smirnova, I. V. (2019). Persuasive Techniques in Advertising. Training, language, and culture. 3(2), 55-70.

Rudolf von Rohr, Marie-Thérèse. (2017). Persuasion in smoking cessation online: An interpersonal pragmatic perspective. Unpublished Ph.D. thesis, University of Basel, Switzerland. Retrieved April 28, 2020 from https://edoc.unibas.ch/66911/

Schmidt, R. and Kess, F.J. (1984). Persuasive Language in Advertising and Televangelism. Working papers of the linguistics circle (WPLC). 4(1), 91-113.

Sexton, S. (2016). Communicating illness: Depictions of mental illness and cancer in Canadian news media. M.A thesis, Ryerson University Toronto, Ontario, Canada. Retrieved July 20, 2020 from https://digital.library.ryerson.ca/islandora/object/RULA\%3A5391

Simatupang, E. C., \& Supri, I. Z. (2020). Compound Words That Occur During the Global Pandemic Covid-19: A Morphosemantic Study. English Review: Journal of English Education. 8(2), 127-134. doi: 10.25134/erjee.v8i2.2824

Soedjarwo, Gabriella. (2020). Persuasion Act in the Proposal Movie. Journal of Pragmatics Research. 2(1), 50-67. Retrieved November 1, 2020 from https:/ejournal.iainsalatiga.ac.id/index.php/jopr/article/view/4584/1561

Sontag, S. (1989). Illness as Metaphor: AIDS and Its Metaphors. New York: Farrar, Straus and Giroux.

Soules, Marshal. (2015). Media, Persuasion, and Propaganda. Edinburgh: Edinburgh University Press.

Tan, K.H., Woods, P., Azman, H., Abdullah, I. H., Hashim, R. S., Abdul Rahim, H., Idrus, M. M., Said, N. E. M., Lew, R., \& Kosem, I. (2020). COVID-19 Insights and Linguistic Methods. 3L: The Southeast Asian Journal of English Language Studies. 26(2), 1-23.

Taufik, K. S., Tarjana, S., \& Nurkamo, Joko. (2014). The Persuasive Utterances in a Political Discourse (The Case Study of the Regent Election Campaign of Pasuruan, East JavaIndonesia). International Journal of Linguistics. 6(1), 192-208.

Van Dijk, T. A. (1996). Power and The News Media. In D. L. Paletz, (Eds.). Political Communication in Action. Cresskill, NJ: Hampton Press.

Vin, Amanda. (2019). Online Activism: Social Change through Social Media. Lucent Press

Virtanen, T. and Halmari, H. (2005). Persuasion across Genres: Emerging Perspectives. In H. Halmari \& T. Virtanen, (Eds.). Persuasion across Genres (pp. 3-24).

Wilson, J. (1990). Politically Speaking. Oxford: Blackwells.

Wu, Ruey-Jiuan. (2011). A Conversation Analysis of Self-Praising in Everyday Mandarin Interaction. Journal of Pragmatics. 43 (13), 3152-3176

Zheng, T. (2000). Characteristics of Australian Political Language Rhetoric: Tactics of Gaining Public Support and Shirking Responsibility. Journal of Intercultural Communication. $\begin{array}{llllll}\text { November (4). Metrieved } 2020 \text { from } & \text { May }\end{array}$ https://www.immi.se/intercultural/nr4/zheng.htm.

\section{ABOUT THE AUTHOR}

Asim Ayed Alkhawaldeh is an assistant professor of English at Department of Modern Languages, Faculty of Arts and Humanities, Al-alBayt University, Jordan. His area of interest includes Discourse Analysis, Pragmatics, Semantics, Historical linguistics, and Corpus Linguistics. 